УДК 159.9:378-051

doi: $10.15330 / p s .9 \cdot 1.51-57$

Галина Дубчак

Відкритий міжнародний університет розвитку людини «Україна»

galyna.dubchak@gmail.com

\title{
ПОРІВНЯЛЬНИЙ АНАЛІЗ ОСОБЛИВОСТЕЙ ДОЛАЮЧОЇ ПОВЕДІНКИ СТУДЕНТІВ ТА ФАХІВЦІВ СОЦІОНОМІЧНИХ ПРОФЕСІЙ
}

\begin{abstract}
У статті обтрунтовано актуальність вивчення проблеми долаючої поведінки фахівців соціономічних професій. Виділено раніше не вирішені частини означеної проблеми, зокрема, вказано на необхідність вивчення психологічних особливостей стратегій долаючої поведінки студентів та фахівців різних соціономічних професій. Описано процедуру дослідження з використанням опитувальника способів подолання (WCQ; Folkman u Lazarus, 1988), адаптованого T. Крюковою у співавторстві, та вибірку, яку склали 198 студентів закладів вищої та середньої освіти м. Чернівці та 214 фахівців, щзо працюють за різними соціономічними професіями. На основі аналізу результатів емпіричного дослідження виокремлено психологічні особливості стратегій подолання стресу сучасних студентів закладів вищої та середньої освіти і працюючих фахівців різних соціономічних професій, визначено їхні спільні та відмінні особливості, а також здійснено порівняльний аналіз стратегій подолання стресу за статтю. З'ясовано, щзо сучасні студенти та фахівці використовують різні стратегії стратегіi долаючої поведінки, однак найбільш вираженими стилями копінг-поведінки є втеча/уникнення, позитивна переоцінка та самоконтроль, найменш вираженими - прийняття відповідальності. Фахівці частіше у стресових ситуаціях використовують стратегії, які відносять до конструктивних, або ж втечу/уникнення, яка в певних ситуаціях може бути досить корисною стратегією поведінки. У поведінці жінок частіше, ніж у чоловіків, домінують механізми прийняття відповідальності та позитивна переоцінка, які зараховують до відносно конструктивних копінг-стратегій. Дослідження дозволило виявити низку проблем, які потребують цілеспрямованої системної роботи, оскільки в усіх групах досліджуваних серед домінуючих виявлено деструктивні копінг-стратегії, а саме, вказано на необхідість спеціально організованої програми з формування стресостійкості майбутніх фахівців сочіономічних професій, професійна діяльність яких є одним із найбільш напружених у психологічному плані видів трудової активності.
\end{abstract} cmpameziï.

Ключові слова: професійна підготовка, соціономічні професії, студенти, стрес, стресостійкість, копінг-

Постановка проблеми та іï зв'язок із важливими науковими i практичними завданнями. Вміння успішно справлятися зі стресом і зводити до мінімуму його негативний вплив є важливим для кожної людини. Передусім рівень психологічної стійкості особистості виявляється в іiі трудовій діяльності, адже стресостійкість визнається одним із факторів, що впливає на ефективність професійної діяльності. 3 іншого боку, успішна професійна діяльність $\epsilon$ основою повноцінної самореалізації, що впливає на задоволеність життям в цілому, на психологічну стійкість.

Особливого значення стійкість до стресу набуває для фахівців соціономічних професій, трудова діяльність яких є одним із найбільш напружених у психологічному плані видів трудової активності.

До соціономічних, за визначенням Є. О. Климова, належать професії, пов’язані з:

- вихованням, навчанням людей (вихователь, учитель);

- медичним обслуговуванням (лікар, фельдшер, медсестра,);

- побутовим обслуговуванням (продавець, перукар, офіціант);

- інформаційним обслуговуванням (бібліотекар, екскурсовод);

- захистом суспільства і держави (юрист, інспектор, військовослужбовець) [2].

На перший погляд, професії цього типу відзначаються відсутністю жорстких і єдиних вимог до самого процесу професійної діяльності, одночасно 3 цим до представників соціономічних професій висуваються підвищені вимоги.

Варто зазначити, що до фахівців будь-якої професії висуваються вимоги двох типів: професійні та психологічні. До професійних вимог можна віднести перелік знань, умінь і навичок, які фіксуються в кваліфікаційній характеристиці або моделі фахівця. Вони 
забезпечуються спеціальною (предметною) підготовкою людини в середньому або вищому навчальному закладі.

Психологічні вимоги присутні в усіх професіях, забезпечуючи засвоєння і виконання багатьох професійних функцій. У переважній більшості випадків їхня присутність невидима. Однак у соціономічних професіях психологічна відповідність виступає ключовим моментом як на етапі входження людини в діяльність, так і на етапі професійної діяльності. Власне, професії цього типу висувають високі вимоги до психіки людини, оскільки вони передбачають інтенсивну взаємодію (спілкування) з широким колом різних людей.

У зв'язку з цим гостро постає питання своєчасної профілактики і корекції постстресових станів та професійного вигорання, які, в першу чергу, мають грунтуватися на повноцінній діагностиці їх ранніх проявів, а також на виявленні індивідуальної схильності конкретної людини до розвитку дистресу i характерних для неї стратегій подолання складних життєвих ситуацій. У зв'язку 3 цим проблема долаючої поведінки набула особливої актуальності.

Аналіз останніх публікацій. Особливим аспектом досліджень проблеми стійкості особистості до стресів $\epsilon$ пошук особистісних ресурсів подолання $[1 ; 3]$. Невипадково досліджувати копінг або подолання (у термінології Л. Анциферової) першими почали клінічні психологи (Р. Лазарус, С. Фолкман, К. Сирота, І. Нікольська, Р. Грановська). Згодом дослідженням долаючої поведінки у стресових ситуаціях були присвячені праці Н. Водоп'янової, Л. Анциферової, В. Бодрова, Т. Крюкової, А. Леонової.

У вітчизняній психології проблемі стресу в цілому присвячено багато публікацій, однак вивчення долаючої поведінки в Україні перебуває на стадії формування [7; 8]. На думку Н. Родіної, дослідження копінгу здебільшого відбуваються на рівні емпіричного виявлення деяких його особливостей у певного контингенту досліджуваних або констатації того, як ці особливості співвідносяться 3 окремими індивідуально-психологічними або соціальнодемографічними характеристиками (О. Назаров, Е. Носенко, I. Корнієнко, Т. Ткачук та ін.). Однак спроби вивчити та узагальнити особливості копінг-поведінки студентів та фахівців соціономічних професій практично відсутні.

Метою статті $\epsilon$ порівняльний аналіз психологічних особливостей стратегій долаючої поведінки студентів та фахівців різних соціономічних професій.

Виклад основного матеріалу дослідження. У широкому розумінні поняття копінгу (від англ. Соре - долати, справлятися 3 чим-небудь) означає спосіб взаємодії особистості 3 проблемною/стресовою чи кризовою для особистості ситуацією [6]. Воно було вперше введено до психології Л. Мерфі у 1962 році, однак головним його дослідником став Р. Лазарус, котрий, визначаючи копінг як прагнення до вирішення проблеми, яке людина проявляє у стресовій ситуації з метою збереження фізичного, особистісного і соціального благополуччя, розробив трифакторну модель копінг-механізмів, що складається 3 копінг-стратегій, копінг-ресурсів i копінг-поведінки [5].

Основою цієї моделі є копінг-стратегії, які Р. Лазарус розуміє як способи управління стресором, який обумовлює поведінку та емоційні реакції на стрес. Копінг-ресурси - це відносно стабільні особистісні характеристики, які забезпечують психологічний фон для подолання стресу і сприяють розвитку копінг-стратегій. Копінг-поведінка - це поведінка, регульована і сформована за допомогою використання копінг-стратегій, 3 урахуванням особистісних і середовищних копінг-ресурсів [5].

Таким чином, психологічне подолання - це когнітивні та поведінкові зусилля особистості, спрямовані на зниження впливу стресу. Головною функцією копінгу є свідомий вибір адекватних, цілеспрямованих дій людини щодо подолання стресогенних впливів ситуації відповідно до своїх потреб та намірів у напрямку відновлення та збереження комфортного психологічного стану [1].

3 метою вивчення основних стратегій долаючої поведінки майбутніх та працюючих фахівців різних соціономічних професій нами було проведено емпіричне дослідження, у якому 
взяло участь 198 студентів закладів вищої та середньої освіти м. Чернівці та 214 фахівців, що працюють за різними соціономічними професіями; всього - 412 осіб. Студенти вузів склали 113

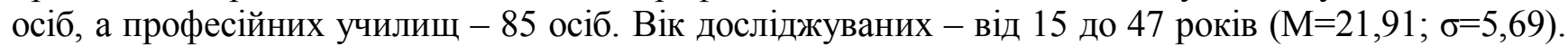
Середній вік фахівців $(\mathrm{M}=24,43 ; \sigma=5,58)$ є істотно вищим, ніж студентів $(\mathrm{M}=19,19 ; \sigma=4,22)$ ( $\leq 00,001)$. Серед досліджуваних було 104 чоловіків та 308 жінок.

У дослідженнях було використано опитувальник способів подолання (WCQ; Folkman i Lazarus, 1988), адаптований Т. Крюковою у співавторстві (2004) [4]. Ця методика використовувалася нами для визначення копінг-стратегій досліджуваних, тобто способів подолання труднощів у різних сферах діяльності, до яких вони вдаються у повсякденному житті.

У роботі були використані статистичні методи обробки емпіричних даних (тест Колмогорова-Смирнова, тест $\chi^{2}, \mathrm{t}$-критерій St'udenta, однофакторний дисперсійний аналіз для незалежних груп). Для статистичного опрацювання була використана комп'ютерна програма SPSS 23.0. Критерій Колмогорова-Смирнова за всіма шкалами підтвердив нормальність розподілу даних $(\mathrm{p}>0,05)$. Це означає, що розподіл можна вважати репрезентативним щодо генеральної сукупності.

Аналіз стратегій долаючої поведінки студентів.

Проаналізуємо передусім дані, отримані за вибіркою студентів. Результати, наведені у таблиці 1 , свідчать про те, що сучасні студенти використовують різні стилі долаючої поведінки.

Аналіз стилів долаючої поведінки студентів (N=198)

\begin{tabular}{|l|c|c|}
\hline \multicolumn{1}{|c|}{ Стиль } & $\mathrm{M}$ & $\sigma$ \\
\hline Конфронтація & 10,41 & 2,74 \\
\hline Дистанціювання & 10,61 & 2,55 \\
\hline Втеча/уникнення & 13,30 & 3,57 \\
\hline Прийняття відповідальності & 7,85 & 1,95 \\
\hline Позитивна переоцінка & 13,09 & 3,31 \\
\hline Пошук соціальної підтримки & 11,24 & 2,74 \\
\hline Планування вирішення проблеми & 11,59 & 2,71 \\
\hline Самоконтроль & 12,96 & 2,87 \\
\hline
\end{tabular}

На основі t-критерію St'udenta встановлено, що для досліджуваної вибірки порівнювана середня величина усіх копінг-стратегій $\epsilon$ істотно вищою від значення 0 ( $<<0,001)$. Це означає, що відмінності в стилях долаючої поведінки студентів є статистично значущими.

Найбільш вираженими стилями копінг-поведінки сучасних студентів є втеча/уникнення $(\mathrm{M}=13,30 ; \sigma=3,57), \quad$ позитивна переоцінка $(\mathrm{M}=13,09 ; \sigma=3,31)$ та самоконтроль $(\mathrm{M}=12,96$; $\sigma=2,87)$, а найменш вираженим - прийняття відповідальності $(\mathrm{M}=7,85 ; \sigma=1,95)$.

Домінуюча в поведінці студентів стратегія втечі/уникнення припускає спроби подолання особистістю негативних переживань у зв'язку з труднощами за рахунок заперечення або повного ігнорування проблеми, фантазування, ухилення від відповідальності та дій по вирішенню виниклих проблем, пасивність, нетерпіння, спалахи роздратування, переїдання, вживання алкоголю тощо з метою зниження болісної емоційної напруги.

Стратегія позитивної переоцінки передбачає вирішення проблеми за рахунок іiі позитивного переосмислення, розгляду іï як стимулу для особистісного зростання. 
Стратегія самоконтролю полягає у мінімізації впливу негативних переживань, пов'язаних з проблемою, на оцінку ситуації і вибір стратегії поведінки, високий контроль поведінки, прагнення до самоопанування. У таких студентів може спостерігатися прагнення приховувати від навколишніх свої переживання у зв'язку з проблемною ситуацією.

Найменш вираженим у нашому дослідженні стилем долаючої поведінки студентів виявилась стратегія прийняття відповідальності. Вона передбачає визнання студентом своєї ролі у виникненні проблеми та відповідальності за їі рішення, у низці випадків з виразним компонентом самокритики і самозвинувачення. Разом з тим вираженість цієї стратегії в поведінці може призводити до невиправданої самокритики, переживання почуття провини $\mathrm{i}$ незадоволеності собою. Зазначені особливості, як відомо, $\epsilon$ фактором ризику розвитку депресивних станів.

На думку авторів методики, усі копінг-механізми за ступенем конструктивності можна віднести до трьох груп: конструктивні (планування рішення, самоконтроль, пошук соціальної підтримки), відносно конструктивні (прийняття відповідальності, позитивна переоцінка) та неконструктивні (конфронтаційний копінг, дистанціювання, втеча/уникнення).

В нашому дослідженні виявлені домінуючі стилі копінг-поведінки студентів належать до усіх трьох груп копінгу, що свідчить про неоднорідність студентського середовища: поруч зі студентами, які, стикаючись із повсякденними труднощами i проблемами, вирішують їх конструктивно або відносно конструктивно, є студенти з недостатньо високими адаптаційними здібностями та деструктивними проявами поведінки. Слід зазначити, що студенти з високим рівнем вияву деструктивних копінг-стратегій можуть потребувати психологічної допомоги.

Порівняльний аналіз стратегій долаючої поведінки студентів та фахівців.

Важливим етапом нашого дослідження став порівняльний аналіз особливостей копінгповедінки студентів та фахівців, результати якого представлено в таблиці 2.

Аналіз стилів поведінки студентів та фахівців ( $\mathrm{N}=412)$

\begin{tabular}{|l|c|c|c|c|c|c|}
\hline \multirow{2}{*}{ Стиль } & \multicolumn{2}{|c|}{ Студенти } & \multicolumn{2}{c|}{ Фахівці } & \multirow{2}{*}{$\mathrm{t}$} & $\mathrm{p}$ \\
\cline { 2 - 5 } & $\mathrm{M}$ & $\sigma$ & $\mathrm{M}$ & $\sigma$ & & \\
\hline Конфронтація & 10,41 & 2,74 & 10,00 & 2,72 & 1,51 & 0,130 \\
\hline Дистанціювання & 10,61 & 2,55 & 10,38 & 2,85 & 0,85 & 0,395 \\
\hline Втеча/уникнення & 12,96 & 2,87 & 13,90 & 3,27 & $-3,06$ & 0,002 \\
\hline Прийняття відповідальності & 11,24 & 2,74 & 11,98 & 2,84 & $-2,68$ & 0,002 \\
\hline Позитивна переоцінка & 7,85 & 1,95 & 8,44 & 2,27 & $-2,81$ & 0,005 \\
\hline Пошук соціальної підтримки & 13,30 & 3,57 & 13,08 & 3,63 & 0,60 & 0,548 \\
\hline Планування вирішення проблеми & 11,59 & 2,71 & 12,22 & 2,84 & $-2,30$ & 0,022 \\
\hline Самоконтроль & 13,09 & 3,31 & 13,75 & 3,39 & $-1,99$ & 0,046 \\
\hline
\end{tabular}

Нами виявлено три типи копінг-стратегій, які максимально виявляються в поведінці фахівців: втеча/уникнення, самоконтроль та пошук соціальної підтримки. Такі ж типи копінгу $є$ максимально вираженими у студентів. Спільним для досліджуваних груп $є$ також те, що ці копінг-механізми за ступенем конструктивності можна віднести до двох протилежних груп: конструктивні (самоконтроль, пошук соціальної підтримки) та деструктивні (втеча/уникнення).

Таким чином, було встановлено, що серед фахівців, як і серед студентів, є такі, які, стикаючись із повсякденними проблемами, вирішують їх конструктивно, та особи з недостатньо 
високими адаптаційними здібностями та деструктивними проявами поведінки. Саме вони можуть потребувати психологічної допомоги.

Аналіз t-критерію St'udenta для незалежних груп виявив значущі відмінності в наступних стилях поведінки фахівців та студентів:

- втеча/уникнення: $\mathrm{t}(410)=-3,06, \mathrm{p} \leq 0,01 ; \mathrm{d}$ Cohena $=0,30$;

- прийняття відповідальності: t $(410=-2,68, \mathrm{p} \leq 0,01, \mathrm{~d}$ Cohena $=0,26$;

- позитивна переоцінка $\mathrm{t}(410)=-2,81, \mathrm{p} \leq 0,01, \mathrm{~d}$ Cohena $=0,28$;

- планування вирішення проблеми $\mathrm{t}(410)=-2,30, \mathrm{p} \leq 0,05, \mathrm{~d}$ Cohena $=0,23$;

- самоконтроль $\mathrm{t}(410)=-1,99, \mathrm{p} \leq 0,05, \mathrm{~d}$ Cohena $=0,20$.

Названі вище типи копінгу є більш вираженими у фахівців, ніж у студентів. Це означає, що фахівці частіше у стресових ситуаціях використовують стратегії, які відносять до конструктивних, або ж втечу/уникнення, яка в певних ситуаціях може бути досить корисною стратегією поведінки. Не є істотними статистично відмінності в стратегіях, спрямованих на пошук соціальної підтримки, дистанціювання та конфронтацію. Слід підкреслити, що два останні типи належать до деструктивних стратегій.

Порівняльний аналіз стратегій долаючої поведінки досліджуваних груп за статтю.

Наступним кроком нашого аналізу було порівняння емпіричних даних копінг-механізмів досліджуваних груп за статтю (див. табл. 3).

Нижче наведені дані показують, що для чоловіків переважаючими типами долаючої $\epsilon$ поведінки $\epsilon$ втеча/уникнення $(\mathrm{M}=12,84 ; \sigma=3,229)$, самоконтроль $(\mathrm{M}=12,83 ; \sigma=3,053)$ та позитивна переоцінка $(\mathrm{M}=12,49 ; \sigma=3,162)$; найменш вираженим стилем $\epsilon$ прийняття відповідальності (M=7,48; $\sigma=1,897)$.

Таблиия 3

Аналіз стилів долаючої поведінки студентів за статтю (N=412)

\begin{tabular}{|l|c|c|c|c|c|c|}
\hline \multirow{2}{*}{ Стиль } & \multicolumn{2}{|c|}{ Хлопці } & \multicolumn{2}{c|}{ Дівчата } & \multirow{2}{*}{$\mathrm{t}$} \\
\cline { 2 - 7 } & $\mathrm{M}$ & $\sigma$ & $\mathrm{M}$ & $\sigma$ & & \\
\hline Конфронтація & 10,41 & 2,717 & 10,41 & 2,791 & 0,01 & 0,98 \\
\hline Дистанціювання & 10,49 & 2,252 & 10,72 & 2,814 & 0,64 & 0,51 \\
\hline Втеча/уникнення & 12,84 & 3,229 & 13,73 & 3,834 & 1,75 & 0,08 \\
\hline Позитивна переоцінка & 12,49 & 3,162 & 13,65 & 3,373 & 2,49 & 0,01 \\
\hline Прийняття відповідальності & 7,48 & 1,897 & 8,20 & 1,960 & 2,61 & 0,01 \\
\hline Самоконтроль & 12,83 & 3,053 & 13,09 & 2,704 & 0,62 & 0,53 \\
\hline Планування вирішення проблеми & 11,92 & 2,383 & 11,28 & 2,976 & $-1,64$ & 0,10 \\
\hline Пошук соціальної підтримки & 11,07 & 2,910 & 11,40 & 2,577 & 0,84 & 0,40 \\
\hline
\end{tabular}

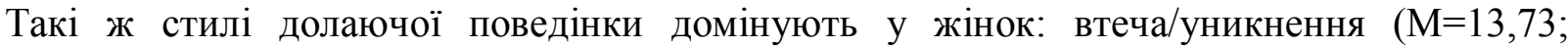
$\sigma=3,834)$, позитивна переоцінка $(\mathrm{M}=13,65 ; \sigma=3,373)$ та самоконтроль $(\mathrm{M}=13,09 ; \sigma=2,704)$; найменш вираженим - прийняття відповідальності $(\mathrm{M}=8,20 ; \sigma=1,96)$.

Аналіз t-критерію St’udenta для незалежних груп виявив значущі відмінності в двох стилях долаючої поведінки студентів хлопців та дівчат: прийняття відповідальності: $\mathrm{t}(410)=$ 2,61, $\mathrm{p}<0,01$ та позитивна переоцінка: $\mathrm{t}(410)=2,49, \mathrm{p}<0,01$.

Таким чином, результати дослідження свідчать, що діагностовано стилі долаючої поведінки, які зараховують до відносно конструктивних, частіше проявляються в поведінці жінок, 
ніж чоловіків. За іншими стилями копінгу відмінності статистично не значущі $(\mathrm{p}>0,05)$.

На основі узагальнення викладеного вище можна зробити наступні висновки:

У стресових ситуаціях сучасні студенти та фахівці використовують різні механізми долаючої поведінки, однак найбільш вираженими стратегіями копінгу є втеча/уникнення, позитивна переоцінка та самоконтроль, а найменш вираженими - прийняття відповідальності.

У поведінці жінок частіше, ніж у чоловіків, домінують механізми прийняття відповідальності та позитивна переоцінка, які зараховують до відносно конструктивних копінгмеханізмів. За іншими стилями копінгу відмінності статистично не значущі.

Оскільки в усіх групах досліджуваних серед домінуючих виявлено деструктивні копінгстратегії, можна говорити про те, що значна частина студентів закладів вищої та середньої освіти та фахівців може мати проблеми у виконанні своїх професійних обов'язків, оскільки вони належать до соціономічних професій.

Таким чином, результати дослідження вказують на необхідність цілеспрямованої роботи 3 формування стресостійкості фахівців соціономічних професій, професійна діяльність яких $\epsilon$ одним із найбільш напружених у психологічному плані видів трудової активності, що буде перспективою наших подальших розвідок у зазначеному напрямі.

1. Вассерман, Л. И., Абабков, В. А., Трифонова, Е. А. (2010). Совладание со стрессом: теория и психодіагностика. СПб.: Речь.

1. Климов, Е. А. (1988). Введение в психологию труда. М.: Изд-во Моск. Ун-та.

2. Корытова, Г. С. (2007). Защитно-совладающее поведение субьекта в профессиональной деятельности. (Дис. док. психол. наук). Иркутский государственный педагогический университет, Иркутск.

3. Крюкова, Т. Л. (2010). Методы изучения совладающего поведения: три копинг-икалы. Кострома: КГУ им. Н. А. Некрасова Авантитул.

4. Лазарус, Р. (1984). Стресс, оценка и копинг. М.: Медицина.

5. Нартова-Бочавер, С. К. (1997). «Coping behavior» в системе понятий психологии личности. Психологический журнал, 18 (5), 20-30.

6. Родіна, Н. В. (2013). Психологія копінг-поведінки: системне моделювання. (Дис. док. психол. наук). Київський національний університет імені Тараса Шевченка, Київ.

7. Ткачук, Т. А. (2011). Копінг-поведінка: стратегї та засоби реалізації: монографія Ірпінь: Нац. ун-т ДПС України.

\section{REFERENCES}

1. Vasserman, L. I. (2010). Sovladanie so stressom: teorija i psihodiagnostika [Coping with stress : theory and psychodiagnostics]. SPb.: Rech. (rus). Un-ta. (rus)

2. Klimov, E. A. (1988). Vvedenie v psihologiju truda [Introduction to the psychology of work]. M. Izd-vo Mosk.

3. Korytova, G. S. (2007). Zashhitno-sovladajushhee povedenie sub'ekta v professional'noj dejatel'nosti [Protective-coping behavior of the subject in professional activity]. (Dis. dok. psihol. nauk). Irkutskii gosudarstvenyi pedagogicheskii universitet, Irkutsk. (rus).

4. Krjukova, T. L. (2010). Metody izuchenija sovladajushhego povedenija: tri koping-shkaly [Methods for studying coping behavior: three copy-scales]. Kostroma, KGU im. N. A. Nekrasova Avantitul. (rus).

5. Lazarus, R. (1984). Stress, ocenka i koping [Stress, evaluation and coping]. M.: Medicina. (rus).

6. Nartova-Bochaver, S. K. (1997). «Coping behavior»v sisteme ponjatij psihologii lichnosti [«Coping behavior» in the system of concepts of the psychology of personality], Psihologicheskij zhurnal, 18 (5), 20-30. (rus).

7. Rodina, N. V. (2013). Psihologija koping-povedinki: sistemne modeljuvannja [Psychology of Coping Behavior: System Simulation]. (Dis. dok. psihol. nauk). Kyivskyi natsionalnyi universytet imeni Tarasa Shevchenka, Kyiv. (ukr).

8. Tkachuk, T. A. (2011). Koping-povedinka: strategï ta zasobi realizaciï [Copy behavior: strategies and means of implementation]. Irpin: Nac. Un-t DPS Ukrainy. (ukr).

\section{Halyna Dubchak \\ COMPARATIVE ANALYSIS OF FEATURES OF COPING BEHAVIOR OF STUDENTS AND PROFESSIONALS OF SOCIONOMIC PROFESSIONS}

The article substantiates the relevance of studying the problem of coping behavior of specialists of socionomic professions. The previously unresolved parts of this problem have been highlighted, in particular, the need to study the 
psychological features of the strategies of overcoming behavior of students and specialists of various socionomic professions. There is described the use of the questionnaire "Ways of Coping» (WCQ, Folkman and Lazarus, 1988) which is adapted by T.L.Kryukova in collaboration (2004) and the research on sample of 198 students of institutions of higher and secondary education in Chernivtsi and 214 specialists working in different socionomic professions. On the basis of the analysis of the results of the empirical research author determined psychological features of the strategies of stress resistance among modern students of institutions of higher and secondary education and working specialists of various socionomic professions. Their common and distinctive features were identified, and a comparative analysis of stress-overcoming strategies by gender was conducted. The results of empirical studies have shown that modern students use various mechanisms of overcoming behaviour in stressful situations, but the most severe coping styles are escapelavoidance, positive reappraisal, and self-control, and the least severe - taking responsibility. The specialists often use constructive styles of coping behaviour or escape/avoidance, which in certain situations can be a good strategy of behaviour. The behavior of women in comparison to men is more often determined by mechanisms of taking responsibility and positive reappraisal, which belong to the relatively constructive coping mechanisms. The research allowed to identify a number of problems that require targeted and systematic work. Destructive coping strategies were found among the dominant strategies in all studied groups, which leads us to the conclusion that there is a need for specially constructed program on the formation of stress resistance of future specialists of socionomic professions, which professional activity is one of the most stressful occupations.

Keywords: professional training, socionomic professions, students, stress, stress resistance, coping-strategies. 